\title{
Purification of Cytochrome P-450alk from $n$-Alkane-grown Cells of Candida maltosa, and Cloning and Nucleotide Sequencing of the Encoding Gene
}

\author{
Masamichi TaKagi, Moriya OhKuma, Norio Kobayashi, \\ Masahiko Watanabe and Keiji Yano \\ Department of Agricultural Chemistry. The University of Tokyo, \\ Bunkyo-ku, Tokyo 113, Japan \\ Received March 10, 1989
}

\begin{abstract}
When the cells of an $\boldsymbol{n}$-alkane-assimilating yeast, Candida maltosa IAM12247, were transferred from a glucose medium to an $\boldsymbol{n}$-alkane medium, various enzymes are induced in the endoplasmic reticulum and peroxisome. Cytochrome $\mathrm{P}-450 \mathrm{alk}$, one of these enzymes in the endoplasmic reticulum, was purified after mild solubilization of the membrane, followed by a few steps of chromatography. The enzyme was characterized spectrophotometrically and its $\mathrm{N}$-terminal amino acid sequence (12 residues) was determined.

Using oligonucleotide probes prepared to match parts of the $\mathrm{N}$-terminal amino acid sequence and " of the partial CDNA sequence of cytochrome P-450alk of $C$. maltosa EH15, we isolated from a gene library of $C$. maltosa IAM12247 a clone which had a gene encoding cytochrome P-450alk. By nucleotide sequencing of this gene, the amino acid sequence of this enzyme was deduced. It consisted of 523 amino acids $(59,838$ daltons), with a non-cleavable signal sequence in the $\mathrm{N}$-terminal region. The structure of this enzyme was compared with some other members of the cytochrome P-450 superfamily.
\end{abstract}

Cytochrome P-450s (P-450s) are hemecontaining monooxygenases which catalyze diverse oxidative reactions in the metabolisms of a large number of endogenous and xenobiotic compounds, and play the major roles in steroid biogenesis, drug metabolism, and chemical carcinogenesis. In higher eukaryotes, there is a P-450 superfamily and the multiple genes encoding P-450s support this diversity. Other than higher eukaryotes, the presence of $\mathrm{P}-450 \mathrm{~s}$ is known in some bacteria and some lower eukaryotes such as yeasts. One of the best characterized P450s in yeasts is $\mathrm{P}-450$ alk in the $n$-alkane-assimilating Candida spp., in both biochemical ${ }^{1 \sim 10)}$ and molecular biologi$\mathrm{cal}^{11,12)}$ aspects. This enzyme, coupled with NADPH-cytochrome P-450-reductase, catalyzes the terminal hydroxylation of $n$-alkane, the first and the rate-limiting step in the assimi- lation pathway. Having a role in carbon source assimilation, the physiological significance of P-450alk is different from those of higher eukaryotes and another P-450 in yeasts, P-450 $14 \mathrm{DM}$, which engages in the biogenesis of ergosterol, the yeast analog of cholesterol. P$45014 D M$ has been found and analyzed in an $n$-alkane-assimilating Candia yeast, ${ }^{13 \sim 15}$ ) Candida albicans ${ }^{16,17)}$ and Saccharomyces cerevisiae. ${ }^{13,18 \sim 21)}$

The transfer of $n$-alkane-assimilating yeast cells from glucose- to $n$-alkane-medium results in the induction of various enzymes including P-450alk, and in the changes in the endoplasmic reticulum (ER) and peroxisome in which these enzymes are located. ${ }^{5 \sim 7}$ ? It has been reported that inducibility of some of these proteins are regulated at the level of transcription. ${ }^{11,22,23)}$ To investigate the detailed mo-

Abbreviations: cytochrome P-450, P-450; ER, endoplasmic reticulum; PMSF, phenylmethylsulfonyl fluoride; DMSO, dimethylsulfoxide; SDS-PAGE, sodium dodecyl sulfate-polyacrylamide gel electrophoresis; HPLC, high performance liquid chromatography; SSC, $0.15 \mathrm{M} \mathrm{NaCl}$ and $0.015 \mathrm{M}$ sodium citrate; kb, kilobase pairs; ORF, open reading frame. 
lecular mechanism of the regulation of gene expression and organelle biogenesis, we have developed genetic systems of Candida maltosa $a^{24 \sim 26)}$ and constructed host-vector systems. $^{27 \sim 29)}$ In this paper are described the purification of $\mathrm{P}-450 \mathrm{alk}$ protein and the isolation and sequencing of a P-450alk-enconding gene from $C$. maltosa. The deduced amino acid sequence is compared to those of some other members of the P-450 superfamily to understand the structure-function relationships amoung P-450s.

\section{Materials and Methods}

Strains and media. The yeast strain used was C. maltosa IAM12247. The MY medium, the minimum medium (the MS medium) and growth conditions were as described previously. ${ }^{23)}$ As a carbon source, $1 \%$ glucose or $n$ tetradecane was added to MS medium. The bacterial strains used were Escherichia coli MC1061 [hsr hsm ${ }^{+}$ araD139 $\Delta($ ara-leu $) 7697$ alacX74 strA GalU ${ }^{-} \mathrm{GalK}^{-}$] and MV1184 [ara $\Delta$ (lac-pro) strA thi ( $\phi 80$ lacZ $\Delta \mathrm{M} 15) \Delta$ (srl-recA) $306:: \operatorname{Tn} 10$ (tet $^{+}$) $\mathrm{F}^{\prime}: \operatorname{traD} 36$ proAB lacl $^{\mathrm{q} Z}$ $\triangle \mathrm{M} 15]$, which was grown in Luria broth.

Purification of P-450alk. P-450alk was purified by a modified procedure of already published methods developed for purification from rat liver ${ }^{30)}$ and from an $n$ alkane-assimilating yeast strain, Lodderomyces elongisporus EH " $\mathrm{D}$ ", ") which is now re-named as Candida maltosa EH15.,10,22) The cells of C. maltosa IAM 12247 grown on $n$-tetradecane using a jar fermenter were collected at middle-log phase and stored at $-80^{\circ} \mathrm{C}$ until use. Preparation of cellular extract, post-mitochondrial supernatant (the PM fraction), and microsomal fraction was done as described previously. ${ }^{23)} \mathrm{A}$ microsomal pellet obtained from 50 to $100 \mathrm{~g}$ of wet cells was suspended in $38 \mathrm{ml}$ of the solubilizing buffer $(50 \mathrm{~mm}$ Tris- $\mathrm{HCl}, \mathrm{pH} 7.5,20 \%$ $(\mathrm{v} / \mathrm{v})$ glycerol, $5 \mathrm{~mm} \beta$-mercaptoethanol, I mM EDTA) containing $0.25 \mathrm{mM}$ PMSF and $0.1 \%$ DMSO, and added to the same volume of $2.4 \%$ sodium cholate in the same solution to solubilize the microsomal membrane mildly. Then the solubilized microsomes were centrifuged at $105,000 \times g$ for $120 \mathrm{~min}$ to obtain solubilized microsomal supernatant (the SM fraction). The SM fraction was put onto a $25-\mathrm{ml}$ column of AH-Sepharose 4B (Pharmacia $\mathrm{Co}$.), and $\mathrm{P}-450$ alk-rich fraction (the $\mathrm{AH}$ fraction) identified by spectrophotometrical analysis was eluted with about $70 \mathrm{ml}$ of the solubilizing buffer containing PMSF and DMSO as described above and $0.4 \%$ sodium cholate and $0.55 \%$ Emulgen 913 (Kao Atlas Co.). About $140 \mathrm{ml}$ of the $\mathrm{AH}$ fraction thus obtained were diluted with $420 \mathrm{ml}$ of the solubilizing buffer to decrease the concentrations of the detergents. The diluted $\mathrm{AH}$ fraction was then put onto a column of DEAE-Sephacel (the volume was $14 \mathrm{ml}$, Pharmacia Co.) and eluted with a linear gradient of $\mathrm{NaCl}$ (from $30 \mathrm{~mm}$ to $120 \mathrm{~mm}$ ) in the solubilizing buffer in which the concentration of Tris- $\mathrm{HCl}$ was decreased to $10 \mathrm{~mm}$, containing $0.1 \%$ Emulgen 913 . Each fraction $(2.7 \mathrm{ml})$ was analyzed spectrophotometrically for P-450alk content, and those fractions rich in P-450alk were pooled (about $22 \mathrm{ml}$, the DE fraction). Ten $\mathrm{ml}$ of the DE fraction was put onto a column of Bio-Gel HTP ( $\mathrm{g}$, Bio-Rad Co.) and eluted with solutions of stepwise increasing concentrations (from $20 \mathrm{~mm}$ to $150 \mathrm{~mm}$ ) of $\mathrm{KH}_{2} \mathrm{PO}_{4}-\mathrm{KOH}$, $\mathrm{pH} 7.5$. The P-450alk-rich fractions eluted with $80 \mathrm{~mm}$ and $100 \mathrm{~mm}$ of $\mathrm{KH}_{2} \mathrm{PO}_{4}-\mathrm{KOH}$ were pooled as the HA fraction. This HA fraction was used as purified P-450alk for characterization of this enzyme. To analyze N-terminal amino acid sequence, the $\mathrm{DE}$ fraction described above containing about $1 \mathrm{nmol}$ of P-450alk was concentrated to about $100 \mu \mathrm{l}$ by a Minicon-B15 (Amicon Corp.) and put onto a column of TSK gel G3000SW $(5.5 \mathrm{~mm} \times 60 \mathrm{~cm}$, Toyo Soda Co.) for HPLC. Elution was done with a solution containing $0.1 \%$ SDS, $4 \%$ glycerol, and $100 \mathrm{~mm} \mathrm{NaCl}$. A P-450alk-rich fraction of $300 \mu \mathrm{l}$ (the $\mathrm{G}$ fraction) was obtained and concentrated to about $100 \mu \mathrm{l}$ before analysis of the Nterminal amino acid sequence by automated Edman degradation in a model 470 protein sequencer (Applied Biosystems.)

Methods for characterization of P-450alk. SDS-PAGE was done as described by Laemmli ${ }^{313}$ using $9 \%$ separating gels. Subunits of heat-resistant RNA polymerase B (Seikagaku Kogyo Co.) were used as molecular weight markers. Spectrophotometrical analyses of P-450alk ${ }^{321}$ and measurement of protein ${ }^{33)}$ were done as described previously.

Construction of a gene library of C. maltosa genome. Total DNA of $\dot{C}$. maltosa was isolated and genomic DNA library was constructed by a modified method described previously. ${ }^{27)}$ In brief, after partial digestion with Sau3A1, $5 \sim 10 \mathrm{~kb}$ genomic DNA fragments were size-fractionated by sucrose density gradient centrifugation. The DNA fragments were ligated to $B g / I I$-digested and phosphatasetreated vector DNA of C. maltosa. This vector, pBTH10B, consisted of pBR322, the TRA sequence ${ }^{27)}$ for autonomous replication in C. maltosa, and the C-HISS gene (manuscript in preparation). Then, E. coli $\mathrm{MCl} 061$ was transformed with the ligated DNA.

Isolation of $m R N A$, synthesis of $c D N A$ probes, and conditions of hybridization. Total RNA of C. maltosa grown on glucose or $n$-tetradecane was isolated by the method using guanidium thiocyanate-cesium chloride. ${ }^{34)}$ Poly(A) ${ }^{+}$-RNA was selected by oligo(dT)-cellulose chromatography. ${ }^{35)} \mathrm{A}$ single strand cDNA probe labeled with $\left[\alpha{ }^{32} \mathrm{P}\right] \mathrm{dCTP}$ (Amersham Co.) was synthesized using a cDNA synthesis kit (Boehringer Mannheim Co.). 
Differential hybridization was done as described previously. ${ }^{36)}$ Colony-blotted or dot-blotted replica filters (Hybond-N, Amersham Co.) were hybridized with a cDNA probe in a solution containing $6 \times \mathrm{SSC}$, $5 \times$ Denhardt solution, $0.1 \%$ SDS, $0.1 \mathrm{mg} / \mathrm{ml}$ denatured salmon sperm DNA, and $0.1 \mathrm{mg} / \mathrm{ml}$ denatured vector pBTH10B DNA after digestion with restriction enzymes. Hybridization was carried out at $65^{\circ} \mathrm{C}$ overnight.

Synthesis of oligonucleotide probes, conditions of hybridization, and DNA sequencing. Oligonucleotide probes were synthesized by the automated phosphoramidite method in a DNA synthesizer (Beckman Co.). They were labeled with $\left[\gamma_{-}{ }^{32} \mathrm{P}\right]$ ATP (Amersham Co.) by T4 polynucleotide kinase (Takara Shuzo Co.). Dot-blotted filters were hybridized with a probe at $58^{\circ} \mathrm{C}$ overnight in a solution containing $6 \times \mathrm{SSC}, 5 \times$ Denhardt solution, $0.1 \%$ $\mathrm{SDS}$, and $0.1 \mathrm{mg} / \mathrm{ml}$ denatured $E$. coli total DNA. Southern hybridization ${ }^{37)}$ and colony hybridization ${ }^{38)}$ were done as described previously. Restriction enzymes and the other enzymes used for DNA manipulation were purchased from Takara Shuzo Co. DNA sequencing was done by the dideoxy sequencing method $^{39)}$ using a kit, Sequenase (Toyobo Co.) or by a automated sequencer, ${ }^{40}$ ) Genesis 2000 DNA Analysis System of E. I. Du Pont. For computer analysis, Genetyx software (SDC-software Development Co.) was used.

\section{Results}

\section{Characterization of purified P-450alk}

P-450alk was purified from the cells grown on $n$-tetradecane as a carbon source. The specific content and the yield of this enzyme in each step of the purification procedure are summarized in Table I. The final specific content was $9.3 \mathrm{nmol} / \mathrm{mg}$ protein. In SDS-PAGE, the HA fraction gave one clear major band of P-450alk and a few faint smear bands of contaminating proteins of high molecular weight. The apparent molecular weight by SDS-
PAGE was 56,000. The theoretical specific content of purified P-450alk is about 18 $\mathrm{nmol} / \mathrm{mg}$ protein when it is calculated from the apparent molecular weight and an assumed millimolar extinction coefficient of $91^{32)}$ for CO-difference spectra. According to this calculation, the purity of our P-450alk preparation was $52 \%$, which was too low compared to the apparent purity judged from the pattern of SDS-PAGE. This difference may be due to the contamination of P-450alk with residual detergents which influence the Lowry method.?

The oxidized form of the purified P-450alk showed a low spin type absorption spectrum with a Soret peak at $418 \mathrm{~nm}$, an $\alpha$ peak at $568 \mathrm{~nm}$, and a $\beta$ peak at $534 \mathrm{~nm}$. A Soret peak of the reduced form was at $420 \mathrm{~nm}$. The reduced CO-complex gave a Soret peak at $450 \mathrm{~nm}$.

The N-terminal amino acid sequence was analyzed using about $0.2 \mathrm{nmol}$ of P-450alk of the $\mathrm{G}$ fraction; it was Ala-Ile-Glu-Gin-IleIle-Glu-Glu-Val-Leu-Pro-Tyr-.

\section{Molecular cloning and sequencing of a gene encoding P-450alk}

A gene for P-450alk was cloned by a twostep procedure. First, since a gene for P-450alk is induced by $n$-alkane in the culture medium, we isolated from a gene library of $C$. maltosa genome those clones which were induced only by $n$-alkane but not by glucose, using a differential hybridization method. Two kinds of cDNA probes, one for mRNA from $n$-tetradecane-grown cells and the other for mRNA from glucose-grown cells, were hybridized separately with $E$. coli colonies carrying a $C$.

Table I. Purification OF Cytochrome P-450alk

\begin{tabular}{ccccc}
\hline Fraction & $\begin{array}{c}\text { Protein } \\
(\mathrm{mg})\end{array}$ & $\begin{array}{c}\text { Cytochrome P-450 } \\
(\mathrm{nmol})\end{array}$ & $\begin{array}{c}\text { Specific content } \\
(\mathrm{nmol} / \mathrm{mg} \text { protein })\end{array}$ & $\begin{array}{c}\text { Yield } \\
(\%)\end{array}$ \\
\hline PM & 1,100 & 39 & $0.034(1)^{a}$ & 100 \\
SM & 130 & 26 & $0.19(5.6)$ & 68 \\
AH & 3.5 & 9.4 & $2.7(80)$ & 24 \\
DE & 0.95 & 4.2 & $4.4(130)$ & 11 \\
HA & 0.056 & 0.52 & $9.3 \quad(270)$ & 1.3 \\
\hline
\end{tabular}

a The ratio of the specific content of cytochrome P-450 in each fraction to that of the PM fraction. 


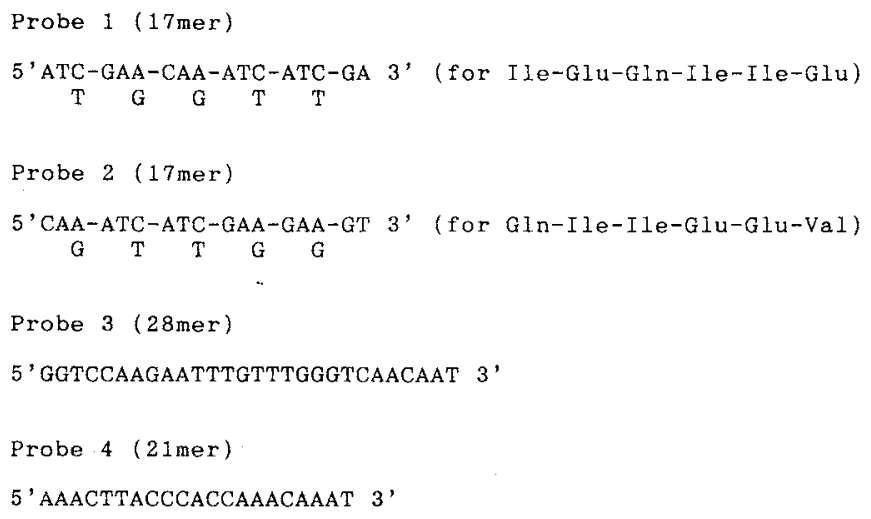

Fig. 1. Synthetic Oligonucleotide Probes.

Probes 1 and 2 were synthesized to match the N-terminal amino acid sequence of purified P-450alk. All the possible codons were used, except for the ATA codon of lle, which has been found to be a rare codon in the $C$ LEU2 gene of C. maltosa. ${ }^{25)}$ Probes 3 and 4 were synthesized to match the information on a partial nucleotide sequence of cDNA for P-450alk of C. maltosa EHI5, which was kindly supplied by Dr. Schunck as described in the test.

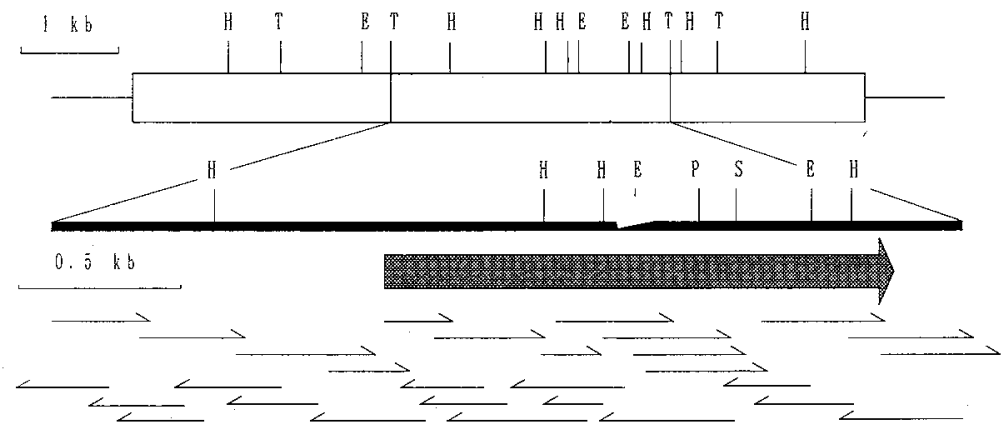

Fig. 2. Restriction Map and Sequencing Strategy for the P-450alk gene.

The thin line indicates the vector sequence, and the open box indicates the C. maltosa DNA sequence. The big arrow represents the open reading frame in the sequenced region. Abbreviations: E, Eco RI; H, HindIII, S, Sal I; P, Pst I, T, EcoT22I.

maltosa genome library. From about 60,000 clones about 2,000 were selected that hybridized specifically with cDNA for mRNA from $n$-tetradecane-grown cells. Then they were examined in the same way again, and about 300 positive clones were isolated. From each of these clones, plasmid DNA was isolated, and dot-blot-hybridization was done using two kinds of cDNA probes. About 50 positive clones were obtained, which were used in the second step.

Then the clones thus selected were screened to detect a clone carrying a gene for P-450alk, using four kinds of synthetic oligonucleotide probes. Probes 1 and 2, which were mixtures of oligonucleotides, were synthesized to match parts of the $\mathrm{N}$-terminal amino acid sequence of purified P-450alk (Fig. 1). Probes 3 and 4 were synthesized to match a partial nucleotide sequence of cDNA (kindly informed us by Dr. Schunck) for P-450alk of $n$-alkane-grown cells of C. maltosa $\mathrm{EH} 15^{9,10,22)}$ (formerly named Lodderomyces elongisporus EH " $D$ ") ${ }^{7)}$ (Fig. $1)$.

The restriction map of the insert in the plasmid carried in this clone is shown in Fig. 2. After subcloning, an EcoT22I DNA fragment having 2803 nucleotides was sequenced, which 


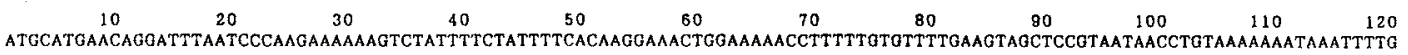
$\begin{array}{ccccccccc}130 & 140 & 150 & 160 & 170 & 180 & 190 & 200 & 210 \\ \text { AAGATTTGACTTGCTGATOAAAATGCTATCAGTGTAGCTCTAGACTTOATACTAGACTATGATGGCAACACATGGTGGTCAACGTGCAAGACATCACCCAATGAGAAGACTGCTAACCAG }\end{array}$

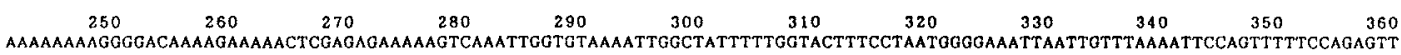
$\begin{array}{cccccccc}370 & 380 & 390 & 400 & 410 & 420 & 430 & 440\end{array}$

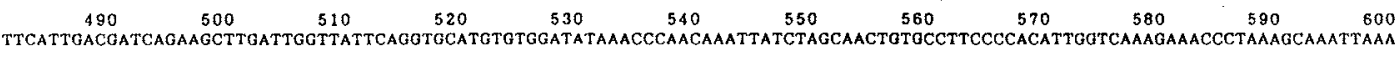
$\begin{array}{ccccccccc}610 & 620 & 630 & 640 & 650 & 660 & 670 & 680 & 680 \\ \text { ATCTGGATAAATAAATCATTCATTTCACATTTTCCGGTTAGTATAAGGTTTTTTAAATTTTTTTTTACAGTTTAGCCCTTTCAATTACCAAATACGGTAACAATGTOCTTTGTAACATGC }\end{array}$ $\begin{array}{ccccccccc}730 & 740 & 750 & 760 & 770 & 780 & 780 & 800 & 810 \\ \text { AGGGGATTTTCTCCGTTGCTGTTTTCTCCACATGCTTTTAATGTGTAATAAATTAAANAAATTACAAAGAAAAACCGGCATATAAGCATCGQAGTTTACATTOTTAACTAACTGCAAAAT }\end{array}$

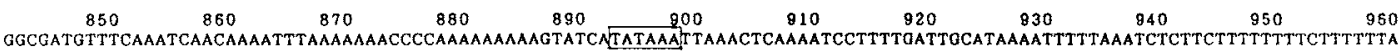

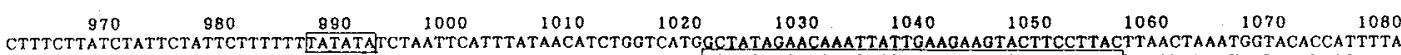

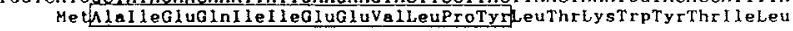

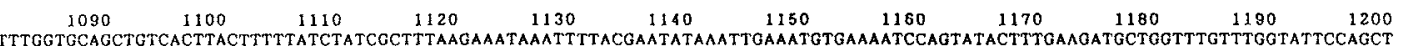

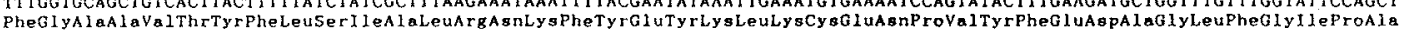

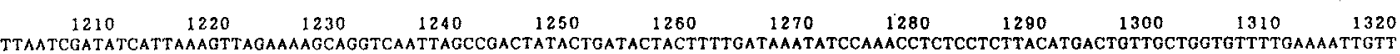

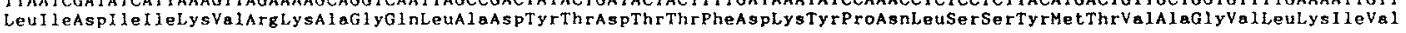

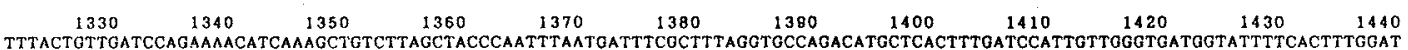

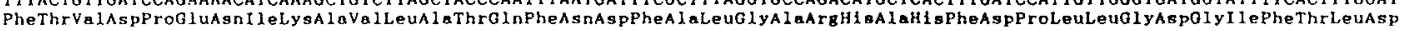

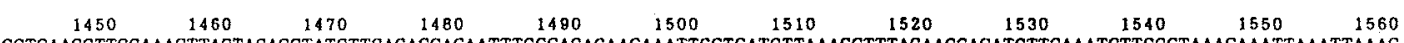
GGTGAAGGTTGGAAACTTAGTAGAGCTATGTTGAGACCACAATTTGCCAGAGAACAAATTGCTCATGTTAAAGCTTTAGAACCACATGTTCAAATCTTGGCTAAACAAATTAAATTAAAC

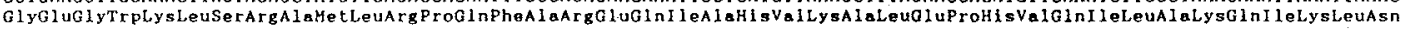

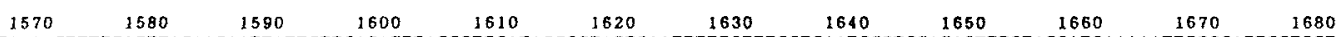
AAGGGTAAAACTTTTOACTTACAAGAATTATTCTTCAGATTTACCGTTGATACCOCTACTGAATTTTTGTTTGGTOAATCCGTCCACAGTTTOTACGATGAAAAATTOGGCATTCCTGCT

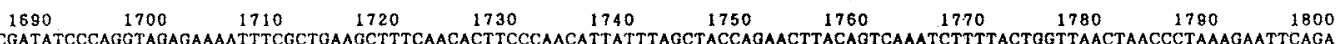

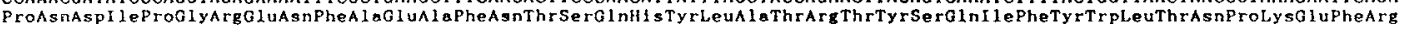

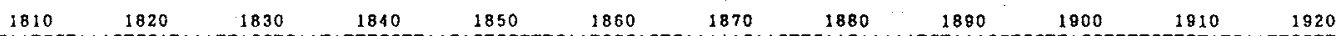
GATTGTAATOCTAAAGTCCATAAATTAGCTCAATATTTCGTTAACACTGCTTTGAATGCCACTGAAAAGAAGTTGAAGAAAATCTAAAGGTGOTTACGTTTTCTTGTATGAATTGGTT

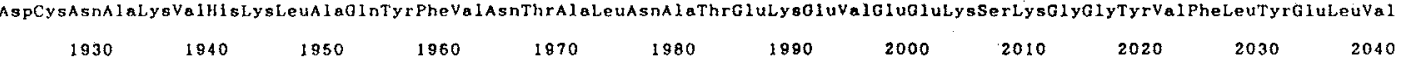
AAACAAACTAGAGATCCAAAAGTTTTGCAAGATCAATTATTAAACATTATGGTTGCCGGTAGAGATACCACTGCAGGTTTATTGTCTTTTGCTATGTTTGAATTGGCCAGAAACCCAAAG

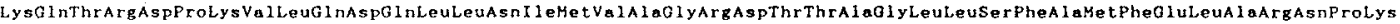


ATTTGGAACAATTGAGAGAAGAGTTGAAGTAATTTCGGATTGGGTGACGAAGCCAGAGTCGACGAAATTTCTTTTGAAACTTTGAAGAAATOTOAATACTTGAAAGCTGTCTTGAAT

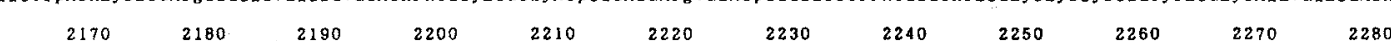
GAAACCTTAAGAATGTATCCTTCCGTCCCAATTAATTTCAGAACTOCTACCAGAGACACAACATTACCAAGAGGTGOTOGTAAAGATGOTAACTCTCCTATCTTTGTTCCAAAAGGTTCT

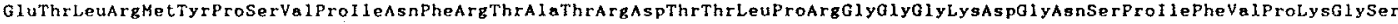

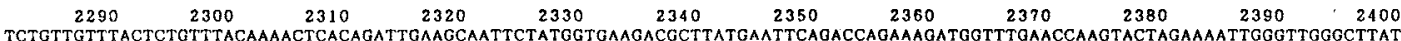

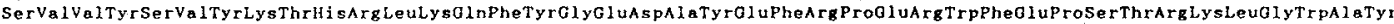

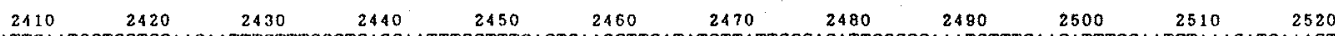

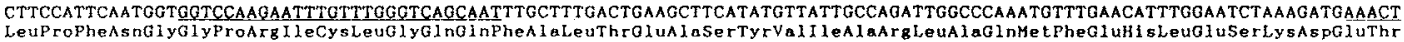

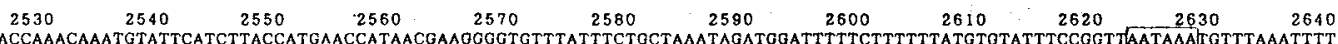

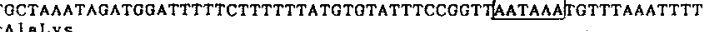

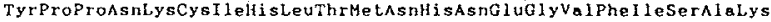

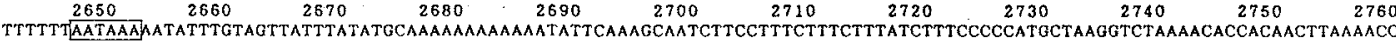
$\begin{array}{ccc}2770 & 2780 & 2790 \\ \text { CAACTTAACCGTATAATACTAAGATCAATCTCCAAAGATGCAT }\end{array}$

Fig. 3. Nucleotide Sequence of the P-450alk gene.

The deduced amino acid sequence is shown under the nucleotide sequence. The sequences of assumed TATA boxes and AATAAA signals, and the amino acid sequence found for purified P-450alk are boxed. The sequences almost identical to those of the synthetic probes 3 and 4 are underlined.

contained a long open reading frame (ORF), as indicated by a large arrow in Fig. 2. The nucleotide sequence and the deduced amino acid sequence are shown in Fig. 3. The ORF starts with ATG at nucleotide 1,018 and ends with TAG at nucleotide 2587, comprising 1569 nucleotides and 523 codons. The deduced molecular weight of this ORF is 59,838 , which is 


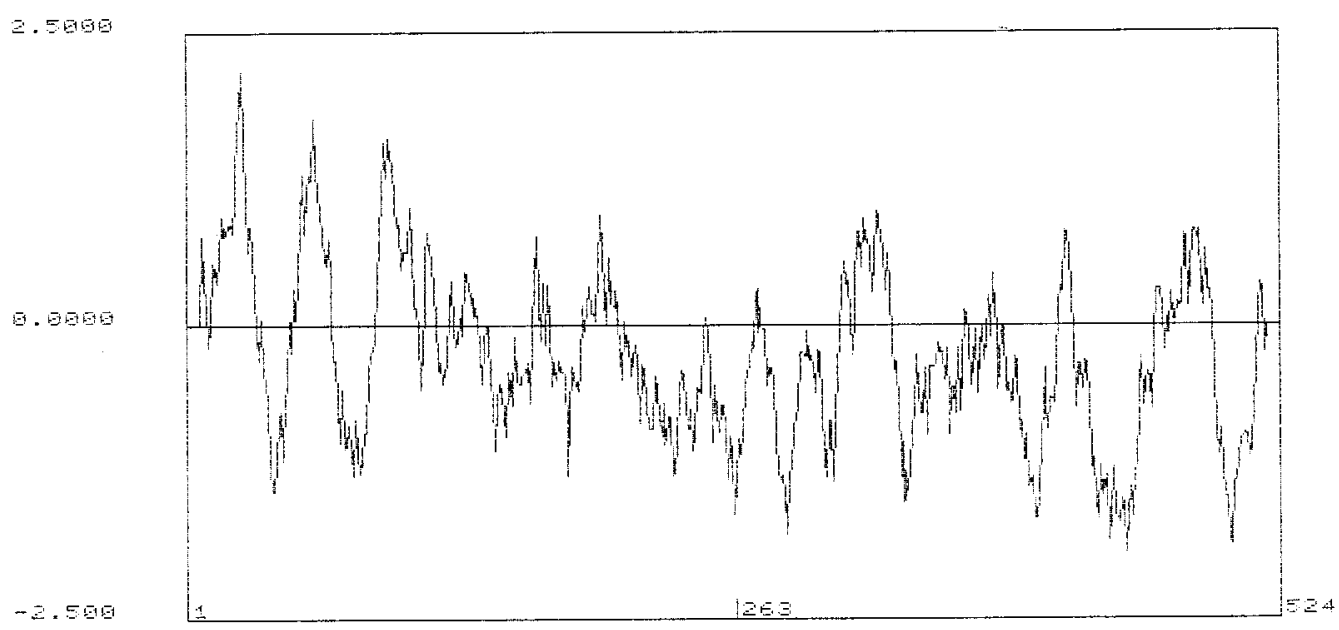

Fig. 4. A Hydropathy Plot of P-450alk.

Hydrophobicity increases from - to + . A standard algorithm with a window of 15 residues is used.

close to the apparent molecular weight $(56,000)$ of purified P-450alk. The deduced sequence of the $\mathrm{N}$-terminal 12 amino acids boxed in Fig. 3 is identical to that of the sequence of purified P-450alk shown above, except for the initial Met. There are sequences, underlined in Fig. 3, which are identical to those of probes 3 and 4 , except for 1 at the nucleotide 2439 .

Two presumptive TATA boxes and AATAAA boxes are found in the 5'- and 3'region of the ORF, respectively, as indicated in Fig. 3.

Of 523 amino acids, $49.7 \%$ are hydrophobic residues (Gly, Ala, Val, Leu, Ile, Met, Phe, Trp, Pro). The hydropathy plot of P-450alk according to Kyte and Doolittle's algorithm ${ }^{41)}$ is shown in Fig. 4.

\section{Comparison of the structure of P-450alk with those of other P-450s}

Recently, Sanglard and Loper ${ }^{12)}$ analyzed the nucleotide sequence of DNA for P-450alk from $C$. tropicalis which is also inducible by and hydroxylates $n$-alkane. Figure 5 shows an alignment of the deduced amino acid sequences of $\mathrm{P}-450 \mathrm{~s}$ from $C$. tropicalis (543 amino acids) and $C$. maltosa (523 amino acids). If some gaps are introduced, 524 are overlapped; 302 amino acids $(57.6 \%)$ are identical and 129 amino acids $(24.6 \%)$ are conservatively replaced.

Alignment of our P-450alk with other kinds of P-450 in yeasts, P-45014DM from S. cerevisiae $^{20)}$ and from $C$. tropicalis $^{15)}$, showed low homology. With P-45014DM from $S$. cerevisiae (530 amino acids), 444 are overlapped and $77(17.3 \%)$ are identical. With that from C. tropicalis (528 amino acids), 373 are overlapped and $68(18.2 \%)$ are identical. Homologous regions are limited only to the $\mathrm{C}$ terminal part, including the HR2 region (see below). This indicates that functionally different P-450s in yeasts, P-450alk and P$45014 D M$, are also different in their structures.

Comparison to the other 8 typical P-450s from 7 vertebrates ${ }^{42 \sim 48)}$ and from Pseudomonas putid ${ }^{49)}$ was done by both sequence alignment and dot matrix. Although homology is low, there are some conserved regions. One of such regions is the previously designated HR2 region. ${ }^{50,51)}$ This region, boxed in Fig. 5, contains an invariant cysteine, which is thought to be the fifth ligand to heme. ${ }^{49}$ ) Other conserved regions, underlined in Fig. 5, are in the C-terminal part of the molecule; a heme-distal helix containing threonine, ${ }^{49}$ and a sequence with a tridecapeptide. ${ }^{52)}$

Among 7 vertebrate $\mathrm{P}-450$ s compared, $\mathrm{P}$ $450 \mathrm{pcnl}$ and $\mathrm{P}-450 L A \omega$ have high similarity to 
$1 "$ MSSSPSIAQEFLATITPYVEYCQENYTKWYYFIPLVILSLNLISMLHTKYLERKFKAKPL

$48^{\prime}$ PVYFEDAGLFGIPALIDI I KVRKAGQLADYTDTTFDKYPNLS--SY $\overline{\text { MTVA-GVLKI - VF }}$

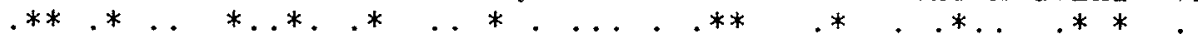

61 " AVYVQDYTFCL ITPLV-LIYYKSKGTVMQFACDLWDKKLIVSDPKAKTIGLKILGIPLIE

103, TVDPENIKAVLATQFNDFALGARHAHFDPLLGDG I FTLDGEGWKLSRAMLRPQFAREQIA $* * * * * . * * . * * * * * * * * . * * . * * . . . . * * * * * * * * * * *, * * * * * . * * * * * * * * * * .$.

$120 "$ TKDPENVKAILATQFNDFSLGTRHDFLYSLLGDG I FTLDGAGW KISR'TMLRPQFAREQVS

$163^{\prime}$ HVKALEPHVQI LAKQI KLNKGKTFDLQELFFRFTVDTATEFLFGESVHSLYDEKLGI-PA $* * * * * * *, * * * * * . . . * . * * * . * * * * * * . * * * . * * * * * . * * * \ldots * * * * \ldots * . *$.

$180 "$ HVKLLEPHMQVLFKHIRKHHGQTFDIQELFFRLTVDSATEFLLGESAESLRDESVGLTPT

$222^{\prime}$ PNDIPGRENFAEAFNTSQHYLATRTYSQIFYWLTNPKEFRDCNAKVHKLAQYFVNTALNA $\ldots * . * * \ldots * * . * * * * * * * * * . * * . * . * * * \ldots * * * * . * \ldots * \ldots * *$.

$240 "$ TKDFDGRNEFADAFNYSQTNQAYRFLLQQMY W ILNGSEFRKS IAI VHIKFADIIYVQKALEL

282 ' TEKEVEEKSKGGYVFLYELVKQTRDPKVLQDQLLLNIMVAGRDTTAGLLSFAMFELARNPK $* \ldots . . * * * . * * * * * . * * . * * * * * * * * * . * * * * * * . * * * * * * * * * * * * * . * * * . * * *$.

$300 "$ TDEDL-EK-KEGYVFLFELAKQTRDPKVLRDQLLNILVAGRD'TTAGLLSFLFFELSRNPE

342 ' IWNKLREEVEVNFGLGDEARVDEISFETLKKCEYLKAVLNETLRMYPSVPINFRTATRDT $* \ldots * * * * * . * . * * * * . . * * * . * * * * * * * * . * * * * * * * . * * * * * . * * * * * * * * . * * * . *$

358" IFAKLREE IENKFGLGQDARVEE ISFETLKSCEYLKAVINETLRIY PSVPINFRVATRNT

402' TLPRGGGKDGNSPIFVPKGSSVVYSVYKTHRLKQFYGEDAYEFRPERWFEPSTRKLGWAY $* * * * * * * \ldots * * * * . * * * * * \ldots * * * * * \ldots * * * * * * * * * * * * * * * . * * * * * * * *$

418 " TLPRGGGEGGLSPIAIKKGQVVMYTILATHRDKDIYGEDAYVFRPERWFEPETRKLGWAY

$462^{\prime}$ LP FNGGPRICLGQQFALTEASYVI ARLAQMFEHL-ESKDETYPPNKC IHLTMNINEGVFI $. * * * * * * * * * * * * * * * * * * * * * * . . * * * * \ldots * \ldots \ldots * \ldots * . . . * * *$

478 " VPFNGGPRICLGQQFALTEASYVTVRLLQEFGNLKQDPNTEYPPKLQNTLTLSLFEGAEV

521 ' SAK

$538^{\prime \prime}$ QMYLIL

Fig. 5. Comparison of the Amino Acid Sequence of P-450alk of C. maltosa (the upper sequence, 523 residues) with That of $C$. tropicalis $^{12)}$ (the lower sequence, 543 residues).

Asterisks indicate identical amino acids, and dots indicate conservatively replaced amino acids in both sequences. Dashes indicate gaps introduced to obtain maximal homology. The HR2 region which contains an invariant cysteine is boxed. Three hydrophobic segments in the N-terminal region are overlined. Other two conservative regions are underlined.

P-450alk; alignments are possible in almost all regions and identical amino acids are $25.6 \%$ and $24.1 \%$, respectively. This suggests that these P-450s may be closer to P-450alk functionally or evolutionarily. In fact, the substrate of $\mathrm{P}-450 L A \omega$, lauric acid, resembles the structure of $n$-alkane, the substrate of P450 alk.

\section{Discussion}

Cytochrome P-450 from $n$-alkane assimilating yeast was first purified and characterized by Riege et al. ${ }^{7)}$ from C. maltosa EH15. The specific content of their purified P-450alk was about $11 \mathrm{nmol} / \mathrm{mg}$ protein. We have tried to trace their experiment to purify $\mathrm{P}-450$ from $C$. maltosa IAM12247, but the specific content and the yield were not as good as expected. 
This difference might be due to the difference of the strains used or of the techniques used during purification in Riege's group and our group. So we modified the procedure of purification of P-450alk and finally succeeded in purification of P-450alk to almost the same extent as reported by Riege et al. ${ }^{7)}$

Although the purity of our P-450alk was theoretically calculated to be $52 \%$, we concluded that the real purity of our preparation judged from the pattern of SDS-PAGE was high enough to be analyzed for its properties and its N-terminal amino acid sequence. In fact, we could determine 12 amino acid residues at the $\mathrm{N}$-terminus. And with information of the $\mathrm{N}$-terminal amino acid sequence and the internal nucleotide sequence of cDNA of P-450alk of C. maltosa EH15 supplied by Dr. Schunck, we could isolate and sequence a gene encoding P-450alk from $C$. maltosa IAM 12247.

The conclusion that the ORF found in the isolated and sequenced DNA fragment shown in Fig. 3 and Fig. 4 encoded the structural gene for P-450alk, was drawn from the following reasons. 1) The expression of this gene is inducible by $n$-alkane and not by glucose. 2) The N-terminal amino acid sequence of the coding ORF is identical to that of purified P450alk, except for the initial Met. 3) The deduced molecular weight of the ORF is very close to the molecular weight of purified P$450 a l k .4)$ It has sequences almost identical to those of the probes, which were prepared according to the sequence data of cDNA for P450 alk from C. maltosa $\mathrm{EH} 15$. 5) Its sequence has high homology to that of DNA for P450 alk of $C$. tropicalis. The last item might also indicate that the genomic DNA sequence of $\mathrm{P}$ 450 alk of $C$. maltosa does not contain any intron, since it was suggested previously that the genomic sequence of P-450alk of $C$. tropicalis does not have any intron. ${ }^{12)}$ This suggestion is supported by the fact that in the ORF there is no TACTAAC sequence which is found typically in the middle of introns of the genes from S. cerevisiae. ${ }^{53)}$

Most of the members of the P-450 super- family so far analyzed are membrane-associated proteins in the ER, and so is the case of P-450alk. The extremely hydrophobic Nterminal region, which is commonly found in these P-450s in the ER, is believed to be responsible for both a signal-recognition-particle dependent, non-cleavable insertion signal into the ER membrane and a stop-transfer sequence. ${ }^{54,55)}$ The $\mathrm{N}$-terminal amino acid sequence of purified P-450alk and the nucleotide sequence of the ORF in the cloned DNA fragment (Fig. 2) indicate that P-450alk is not cleaved like the other P-450s in the ER. It is found that the $\mathrm{N}$-terminal region has the highest hydrophobicity in P-450alk (Fig. 3), which is composed of three hydrophobic segments overlined in Fig. 5; the first 25 amino acid segment from position 10 to 34 , the second 13 amino acid segment from 54 to 66 , and the third 12 amino acid segment from 92 to 103 . Probably the first segment is mainly responsible for translocation of this protein into the membrane on the basis that it is extremely hydrophobic, that it has a proper length required for membrane spanning, and that it is followed by a sequence with charged amino acid residues proposed as a putative halt-transfer signal. The second and third segments are followed by charged residues too, but they are slightly too short to span the membrane. Between these three segments, there are considerably hydrophilic segments. This typical feature leads us to think that the N-terminal part of P-450alk may cross the ER membrane a few times.

One of our main interests is to understand the molecular mechanisms of induction of various genes of enzymes by $n$-alkane in $C$. maltosa, which we believe is a suitable model system to investigate regulation of gene expression by hydrophobic compounds. The cloning of these genomic genes is a necessary step for this purpose. The next step would be to assay promoter activity of the P-450alk gene in the presence of various carbon sources, to analyze $c i s$-element(s) in the $5^{\prime}$-flanking region of the gene responsible for induction, and to find trans-element(s) which interacts with the 
cis-element(s). For these kinds of investigations, out host-vector system of $C$. maltosa ${ }^{27 \sim 29)}$ should be powerful and indispensable tools. Furthermore, other genes for proteins induced by carbon sources in $n$-alkaneassimilating yeasts such as peroxisomal fatty acyl coenzyme A oxidase ${ }^{56.57)}$ will also be useful for these investigations. Isolation of genes with this characteristic other than the gene for P-450alk is being done in our laboratory using the clones isolated by the differential hybridization experiments described in this paper.

Acknowledgments. We thank Dr. Schunck of the Central Institute of Molecular Biology, Academy of Sciences of the GDR, and Dr. Sanglard of Eidg. Technische Hochschule Zürich, Institut für Biotechnologie, for showing us the unpublished data of cDNA sequence and genomic DNA sequence, respectively, of P-450alk form Candida yeasts. We also thank Dr. Nagasawa of The University of Tokyo for his help and advice in the analysis of the amino acid sequence of $P$ 450 alk. This work was supported in part by a Grant-inAid for Scientfic Research from the Ministry of Education, Science and Culture of Japan.

\section{References}

1) J. M. Lebeault, E. T. Lode and M. J. Coon, Biochem. Biophys. Res. Commun., 42, 413 (1971).

2) W. Duppel, J. M. Lebeault and M. J. Coon, Eur. J. Biochem., 36, 583 (1973).

3) M. Gallo, J. C. Bertrand, B. Roche and E. Azoulay, Biochim. Biophys. Acta, 296, 624 (1973).

4) S. Fukui and A. Tanaka, Trends Biochem. Sci., 4, 246 (1979).

5) M. Takagi, K. Moriya and K. Yano, Cell. Molecul. Biol., 25, 363 (1980).

6) S. Fukui and A. Tanaka, Adv. Biochem. Eng., 19, 217 (1981).

7) P. Riege, W.-H. Schunck, H. Honeck and H.-G. Muller, Biochem. Biophys. Res. Commun., 98, 527 (1981).

8) E. Kargel, W.-H Schunck, P. Riegel, E. Honeck, P. Claus, H.-P. Kleber and H.-G. Muller, Biochem. Biophys. Res. Commun., 128, 1261 (1985).

9) W.-H. Schunck, S. Mauersberger, J. Huth, P. Riege and H.-G. Muller, Arch. Microbiol., 147, 240 (1987).

10) W.-H. Schunck, S. Mauersberger, E. Kargel, J. Huth and H.-G. Muller, Arch. Microbiol., 147, 245 (1987).

11) D. Sangland, C. Chen and J. C. Loper, Biochem. Biophys. Res. Commun., 144, 251 (1987).

12) D. Sanglard and J. C. Loper, Gene, in press (1989).
13) D. Sangland, O. Kappeli and A. Fiechter, $J$. Bacteriol., 157, 297 (1984).

14) C. Chen, T. G. Turi, D. Sanglard and J. C. Loper, Biochem. Biophys. Res. Commun., 146, 1311 (1987).

15) C. Chen, V. F. Kalb, T. G. Turi and J. C. Loper, DNA, 7, 617 (1988).

16) D. R. Kirsch, M. H. Lai and J. O. O'Sullivan, Gene, 68, 229 (1988).

17) M. H. Lai and D. R. Kirsch, Nucleic Acids Res., 17, 804 (1989).

18) Y. Yoshida and Y. Aoyama, J. Biol. Chem., 259, 1655 (1984)

19) V. F. Kalb, J. C. Loper, C. R. Dey, C. W. Woods and T. R. Sutter, Gene, 45, 237 (1986).

20) V. F. Kalb, C. W. Woods, T. G. Turi, C. R. Dey, T. R. Sutter and J. C. Loper, DNA, 6, 529 (1987).

21) N. Ishida, Y. Aoyama, R. Hatanaka, Y. Oyama, S. Imajo, M. Ishiguro, T. Oshima, H. Nakazato, T. Noguchi, U. S. Maitra, V. P. Mohan, D. B. Sprinson and Y. Yoshida, Biochem. Biophys. Res. Commun., 155, 317 (1988).

22) B. Wiedmann, M. Wiedmann, E. Kargel, W.-H. Schunck and H.-G. Muller, Biochem. Biophys. Res. Commun., 136, 1148 (1986).

23) M. Sunairi, K. Watabe, M. Takagi and K. Yano, $J$. Bacteriol., 160, 1037 (1984).

24) M. Kawamura, M. Takagi and K. Yano, Gene, 24, 157 (1983).

25) M. Takagi, N. Kobayashi, M. Sugimoto, T. Fujii, J. Watari and K. Yano, Curr. Genet., 11, 451 (1987).

26) M. Sunairi, R. Suzuki, M. Takagi and K. Yano, Agric. Biol. Chem., 52, 577 (1988).

27) M. Takagi, S. Kawai, M. C. Chang, I. Shibuya and K. Yano, J. Bacteriol., 167, 551 (1986).

28) S. Kawai, C. W. Hwang, M. Sugimoto, M. Takagi and K. Yano, Agric. Biol. Chem., 51, 1587 (1987).

29) M. Takagi, S. Uchino, M. Sugimoto, S. Kawai, T. Hikiji and K. Yano, J. Basic Microbiol., 28, 335 (1988).

30) Y. Imai and R. Sato, J. Biochem., 75, 689 (1974).

31) U. K. Laemmli, Nature, 227, 680 (1970).

32) T. Omura and R. Sato, J. Biol. Chem., 239, 2370 (1964).

33) O. H. Lowry, N. J. Rosebrough, A. L. Farr and R. J. Randall, J. Biol. Chem., 193, 265 (1951).

34) J. M. Chirgwin, A. E. Przybyla, R. J. MacDonald and W. J. Rutter, Biochemistry, 18, 5294 (1979).

35) H. Aviv and P. Leder, Proc. Natl. Acad. Sci. U.S.A., 69, 1408 (1972).

36) T. P. St. John and R. W. Davis, Cell, 16, 443 (1979).

37) E. M. Southern, J. Mol. Biol., 98, 503 (1975).

38) H. Horiuchi, K. Yanai, T. Okazaki, M. Takagi and K. Yano, J. Bacteriol., 170, 272 (1988).

39) F. Sanger, S. Nicklen and A. R. Coulson, Proc. Natl. Acad. Sci. U.S.A., 74, 5463 (1977).

40) J. M. Prober, G. L. Trainor, R. J. Dam, F. W. Hobbs, C. W. Robertson, R. J. Zagursky, A. J. 
Cocuzza, M. A. Jensen and K. Baumeister, Science, 238, 336 (1987).

41) J. Kyte and R. F. Doolittle, J. Mol. Biol., 157, 105 (1982).

42) Y. Fujii-Kuriyama, Y. Mizukami, K. Kawajiri, K. Sogawa and M. Muramatsu, Proc. Natl. Acad. Sci. U.S.A., 79, 2793 (1982)

43) K. Morohashi, Y. Fujii-Kuriyama, Y. Okada, K. Sogawa, T. Hirose, S. Inayama and T. Omura, Proc. Natl. Acad. Sci. U.S.A., 81, 4647 (1984).

44) K. Sogawa, O. Gotoh, K. Kawajiri and Y. FujiKuriyama, Proc. Natl. Acad. Sci. U.S.A., 81, 5066 (1984).

45) F. J. Gonzalez, D. W. Nebert, J. P. Hardwick and C. B. Kasper, J. Biol. Chem., 260, 7435 (1985).

46) H. Yoshikawa, K. Morohashi, K. Sogawa, M. Yamane, S. Kominami, S. Takemori, Y. Okada, T. Omura and Y. Fujii-Kuriyama, J. Biol. Chem., 261, 4106 (1986).

47) M. X. Zuber, M. E. John, T. Okamura, E. R. Simpson and M. R. Waterman, J. Biol. Chem., 261, 2475 (1986).
48) J. P. Hardwick, B.-J. Song, E. Huberman and F. J. Gonzalez, J. Biol. Chem., 262, 801 (1987).

49) B. P. Unger, I. C. Gunsalus and S. G. Slingar, J. Biol. Chem., 261, 1158 (1986).

50) O. Gotoh, Y. Tagashira, T. Iizuka and Y. FujiiKuriyama, J. Biochem., 93, 807 (1983).

51) V. F. Kalb and J. C. Loper, Proc. Natl. Acad. Sci. U.S.A., 85, 7221 (1988).

52) J. Ozols, F. S. Heinemann and E. F. Johnson, J. Biol. Chem., 256, 11405 (1981).

53) C. J. Langford, F.-J. Klinz, C. Donath and D. Gallwith, Cell, 36, 645 (1984).

54) E. Szczesna-Skorupa, N. Browne, D Mead and B. Kemper, Proc. Natl. Acad. Sci. U.S.A., 85, 738 (1988).

55) S. Monier, P. V. Luc, G. Krebich, D. D. Sabatini and M. Adesnik, J. Cell Biol., 107, 457 (1988).

56) K. Okazaki, T. Takeuchi, N. Kambara, S. Fukui, I. Kubota and T. Kamiryo, Proc. Natl. Acad. Sci. U.S.A., 83, 1232 (1986).

57) K. Okazaki, H. Tan, S. Fukui, I. Kubota and T. Kamiryo, Gene, 58, 37 (1987). 